Proc. Estonian Acad. Sci. Biol. Ecol., 2005, 54, 4, 335-341

\title{
Comparison of the influence of an artificial and a natural soil on the behaviour of Enchytraeus albidus - laboratory tests
}

\author{
Mónica Amorim ${ }^{\mathrm{a} *}$, Amadeu Soares ${ }^{\mathrm{a}}$, and Jörg Römbke \\ a Department of Biology, University of Aveiro, 3810-193 Aveiro, Portugal \\ ${ }^{\mathrm{b}}$ ECT Oekotoxikologie GmbH, D-65439 Flörsheim, Germany
}

Received 13 October 2004, in revised form 30 June 2005

\begin{abstract}
Enchytraeids are able to avoid unfavourable environmental conditions, especially contaminated areas. Tests were made in order to compare the toxicity in two different soils: OECD artificial soil and LUFA 2.2 natural standard soil. Enchytraeids were exposed to the soils spiked with the fungicides Benomyl and Carbendazim and the herbicide Phenmedipham. The results indicate that the tested soils induced different effects on the organisms: LUFA 2.2 soil was apparently preferred by the organisms and allowed more accurate effect level concentration calculations.
\end{abstract}

Key words: Oligochaeta, laboratory tests, pesticides, behavioural endpoint.

\section{INTRODUCTION}

Environmental risk assessment is commonly based on bioassays that reflect acute and chronic effects. Common examples are the evaluation of mortality and reproduction. These are relevant endpoints but although the tests are cost effective they are time consuming. Therefore, an alternative would be well accepted. Avoidance tests are based on the fact that oligochaete worms such as enchytraeids possess chemoreceptors highly sensitive to chemicals in their environment (Edwards \& Bohlen 1996, Römbke \& Schmidt 1999). Avoidance behaviour is an ecologically relevant measurement endpoint because it influences the energy budget of the individual worms and indirectly also the soil structure. While the

${ }^{*}$ Corresponding author, mjamorim@bio.ua.pt 
avoidance behaviour of earthworms is relatively well established (Yeardley et al. 1996, Slimak 1997, Stephenson et al. 1997, Hund 1998), the behaviour of enchytraeids remains to be studied. In addition, it is not known what influence certain soil properties might have on the avoidance behaviour in the presence of chemicals. An optimum control (e.g. OECD artificial soil or LUFA 2.2 natural soil) has to be identified. The objectives of this study are to compare the differences between OECD artificial soil and LUFA 2.2 soil in terms of effects on the organisms with and without interaction between soil properties and chemical substances.

\section{MATERIAL AND METHODS}

\section{Test organism}

The test organism used belongs to the species Enchytraeus albidus Henle, 1837. Individuals were maintained in laboratory cultures, kept in the dark at $20^{\circ} \mathrm{C}$, and fed once a week with finely ground and autoclaved rolled oats (Cimarrom, Portugal). Details of the culturing process are given in Römbke \& Moser (2002).

\section{Soils}

The artificial OECD soil (OECD 1984) and the natural standard soil LUFA 2.2 (Løkke \& van Gestel 1998) were used as reference soils for comparison purposes. The two soils were spiked with several chemical substances: the herbicide Phenmedipham (1-3.2-10-32-100 $\mathrm{mg} / \mathrm{kg})$ and the fungicides Benomyl (0.32-1$3.2-10-32 \mathrm{mg} / \mathrm{kg}$ ) and Carbendazim $(0.32-1-3.2-10-32 \mathrm{mg} / \mathrm{kg}$ ), all concentrations are given as active ingredient (a.i.) per kg soil (dry weight). After the homogeneous mixing of the pre-moistened soils, the soil was introduced into the test vessels.

Artificial soil (OECD 1984) is constituted by $69 \%$ sand, $20 \%$ kaolin clay, $10 \%$ sphagnum peat, and $0.3-1 \%$ of $\mathrm{CaCO}_{3}$ for $\mathrm{pH}$ adjustment $(6 \pm 0.5)$. LUFA 2.2 is a natural standard soil from the Landwirtschaftliche Untersuchungs- und Forschungsanstalt (LUFA) in Speyer, Germany. The properties of the soils tested are presented in Table 1.

Table 1. Properties of the tested soils

\begin{tabular}{l|c|c|c|c|r|c|c|c}
\hline \multirow{2}{*}{ Soil } & $\begin{array}{c}\mathrm{pH} \\
\left(\mathrm{CaCl}_{2}\right)\end{array}$ & $\begin{array}{c}\mathrm{OM}^{\mathrm{a}} \\
\%\end{array}$ & $\mathrm{C} / \mathrm{N}$ & \multicolumn{2}{|c|}{ Grain-size distribution, \% } & \multirow{2}{*}{$\begin{array}{c}\mathrm{CEC}^{\mathrm{b}}, \\
\text { mval/100 } \mathrm{g}\end{array}$} & $\begin{array}{c}\mathrm{WHC}^{\mathrm{c}}, \\
\%\end{array}$ \\
\hline OECD artificial & 6.0 & 9.0 & 107.5 & 15 & 9 & 76 & 45.8 & 58 \\
LUFA 2.2 & 5.5 & 3.9 & 13.5 & 6 & 17 & 77 & 11.2 & 55
\end{tabular}

${ }^{\mathrm{a}} \mathrm{OM}$ - organic matter; ${ }^{\mathrm{b}} \mathrm{CEC}$ - cation exchange capacity; ${ }^{\mathrm{c}} \mathrm{WHC}$ - water holding capacity. 


\section{Experimental procedure}

The experimental material and procedures used in these experiments are very simple: plastic boxes $(8 \times 5 \times 10 \mathrm{~cm})$ and a movable wall that divides the box in two halves. Figure 1 schematizes the test procedures. Prior to the introduction of the soils ( $25 \mathrm{~g}$ in both sides), the wall is placed at the centre of the box and the control soil is introduced in one side of the vessel and the test soil in the other. After this, the wall is gently removed and ten adult enchytraeid worms are left on the contact line of the soils. The box is covered with a lid (containing small holes) and the test is run for $48 \mathrm{~h}$ at $20^{\circ} \mathrm{C}$ with a $16: 8 \mathrm{~h}$ light:dark period. Five replicates per treatment are used. At the end of the test the movable wall is placed back in the centre, and each side of the box is independently searched for worms.

\section{Statistics}

Calculations were performed using the statistical software package SPSS 12.0. The avoidance effect expresses the percentage of affected worms (i.e. those that avoided the treated part of the test vessel), and was used as an endpoint. The values of $\mathrm{EC}_{50}$ were calculated as Probit regression, assuming that in the control $50 \%$ of the worms are in each side of the vessel (no effect).

Results are presented in graphs in terms of average net response (NR) expressed as percentage and calculated as follows:

$$
\mathrm{NR}=((\mathrm{C}-\mathrm{T}) / \mathrm{N}) \times 100,
$$

where $\mathrm{C}$ designates the worms observed in the control soil, $\mathrm{T}$ stands for the worms observed in the test soil, and $\mathrm{N}$ is the total number of worms per replicate.

A positive $(+)$ net response indicates avoidance and a negative net response $(-)$ indicates a non-response (or attraction) to the chemical or different soil tested.
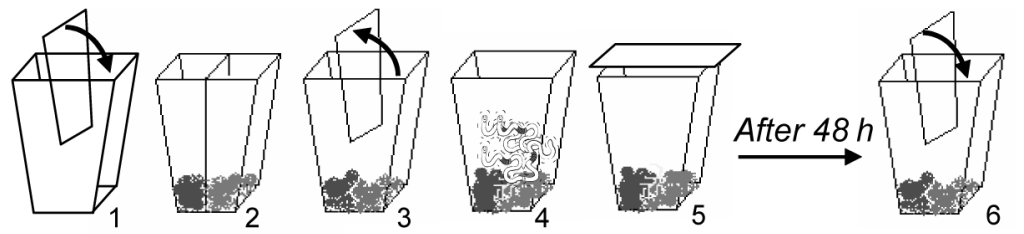

Fig. 1. Scheme of the test procedures: (1) Introduction of the movable wall in the centre of the test vessel; (2) Introduction of the soils to be tested in each side (control versus spiked soil); (3) Movable wall is removed; (4) Introduction of ten enchytraeid worms in the centre of the vessel; (5) Covering the test vessel with a lid (perforated); 48 hours period (16:8 h light:dark; $\left.20 \pm 2{ }^{\circ} \mathrm{C}\right)$; (6) Reintroduction of the wall to separate the soils and counting of the organisms present in each side. 
In accordance with the previously mentioned Draft Guideline for the Earthworm Avoidance Test (ISO 2004), the habitat function of soils is considered to be limited if on average $>80 \%$ of the worms are found in the control soil (indication of an impact on behaviour).

\section{RESULTS AND DISCUSSION}

\section{OECD artificial soil vs. LUFA 2.2 natural soil}

Enchytraeids showed a clear preference for LUFA 2.2 soil (Fig. 2) in both experiments, probably because this natural standard soil fulfils the needs of Enchytraeus albidus better than the OECD artificial soil.

\section{Avoidance towards different chemical substances}

The effect of soil type was found to be statistically significant $(p<0.001)$. However, the effect of the concentrations of the chemicals tested was not statistically significant ( $p=0.050)$ (Fig. 3).

In all cases, OECD soil was less suitable for the worms and a more distinct response can be gained from studies in which LUFA 2.2 soil is used as control; probably because the natural soil fulfils the needs of Enchytraeus albidus better than the artificial soil. In addition, the high organic matter content of the latter might be responsible for a higher adsorption of the test chemical, leading to an unequal distribution and a lower bioavailability of the test chemicals than in the LUFA soil. In the former case, the worms may be trapped in a "hotspot" (meaning highly toxic spots, where the worms remained trapped) or else may not realise that there is a contaminant at all. As a result, the chemical becomes less noticed by the worms and is less avoided.

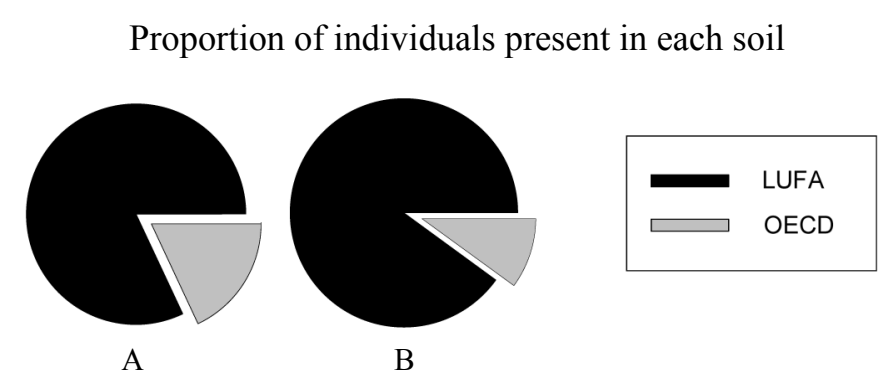

Fig. 2. Results, in terms of number of individuals, of the exposure to OECD artificial soil vs. LUFA 2.2 standard soil as control, performed in two experimental sets (A, B). 


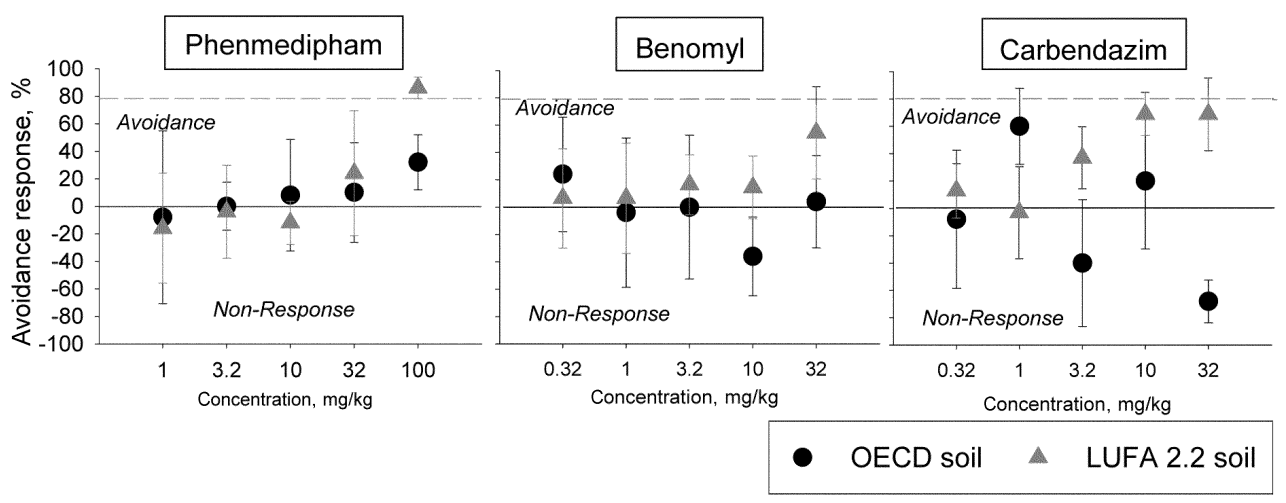

Fig. 3. Avoidance tests with Phenmedipham, Benomyl, and Carbendazim spiked into OECD artificial and LUFA 2.2 natural soil. Graphs show \% of avoidance \pm standard error. Dashed line at $80 \%$ : the habitat function of soils is considered to be limited if on average $>80 \%$ of worms are found in the control soil (indication of an impact on behaviour) (ISO 2004).

The $\mathrm{EC}_{50}$ values of avoidance, acute and chronic tests are listed in Table 2. The last two data sets were gained in Enchytraeid Reproduction tests (Römbke \& Moser 2002, ISO 2003, Amorim et al. 2005). One can observe that:

- The $\mathrm{EC}_{50}$ values for avoidance were higher than the $\mathrm{EC}_{50}$ values for reproduction;

- In comparison to the acute $\mathrm{LC}_{50}$ values, the results of the avoidance tests are mostly in the same order of magnitude.

Table 2. $\mathrm{EC}_{50}$ and $\mathrm{LC}_{50}$ values of the experiments performed with the toxic substances

\begin{tabular}{|c|c|c|c|}
\hline Experiment & $\begin{array}{c}\text { Avoidance } \\
\mathrm{EC}_{50}, \mathrm{mg} / \mathrm{kg}\end{array}$ & $\begin{array}{c}\text { Survival }^{\mathrm{a}} \\
\mathrm{LC}_{50}, \mathrm{mg} / \mathrm{kg}\end{array}$ & $\begin{array}{l}\text { Reproduction }^{\mathrm{a}} \\
\mathrm{EC}_{50}, \mathrm{mg} / \mathrm{kg}\end{array}$ \\
\hline LUFA 2.2 + Benomyl & 46.8 & 1.8 & 1 \\
\hline OECD + Benomyl & $>32.0$ & 25.7 & 5 \\
\hline LUFA $2.2+$ Carbendazim & 7.9 & $2.5^{\mathrm{b}}$ & $0.8^{\mathrm{b}}$ \\
\hline OECD + Carbendazim & $>32.0$ & 4.9 & 3.7 \\
\hline LUFA 2.2 + Phenmedipham & 50.7 & 56.6 & 31 \\
\hline OECD + Phenmedipham & 252.2 & $>100$ & 46 \\
\hline
\end{tabular}

a After Römbke \& Moser 2002, ISO 2003, Amorim et al. 2005.

b Estimated based on a test with a loamy field soil (Römbke \& Federschmidt 1995). 


\section{MAIN CONCLUSIONS}

In agreement with the few studies performed so far with enchytraeids in avoidance tests (e.g. Achazi et al. 1999), the following conclusions can be drawn:

1. Enchytraeus albidus is a suitable test organism for testing avoidance.

2. LUFA 2.2 soil seems to be the best choice for substrate testing and/or as a control soil.

3. Avoidance tests are useful as a screening tool for the assessment of potentially contaminated soils.

4. In addition, they are valuable in evaluating the influence of soil properties on Enchytraeus albidus.

For these reasons this test should be standardized in the same way as the earthworm avoidance test is currently standardized by ISO (ISO 2004).

\section{ACKNOWLEDGEMENTS}

This study was sponsored by Fundação para a Ciência e Tecnologia, Portugal, through a PhD grant to Mónica Amorim (SFRH/BD 1348/2000).

\section{REFERENCES}

Achazi, R. K., Fröhlich, E., Henneken, M. \& Pilz, C. 1999. The effect of soil from former irrigation fields and of sewage sludge on dispersal activity and colonizing success of the annelid Enchytraeus crypticus (Enchytraeidae, Oligochaeta). Newsl. Enchytraeidae, 6, 117-126.

Amorim, M. J., Scheffczyk, A., Römbke, J. \& Soares, A. M. V. M. 2005. Effect of different soil types on the enchytraeids Enchytraeus albidus and Enchytraeus luxuriosus using the herbicide Phenmedipham. Chemosphere, 61(8) (in press).

Edwards, C. A. \& Bohlen, P. J. 1996. Biology of Earthworms. Third Edition. Chapman and Hall, London.

Hund, K. 1998. Earthworm avoidance test for soil assessment: alternative for acute and reproduction test. In Contaminated Soil '98, Conference Proceedings, Sixth International FZK/TNO Conference on Contaminated Soil, pp. 1039-1040. Thomas Telford Publishing, London.

ISO (International Organization for Standardization). 2003. Soil quality - Effects of pollutants on Enchytraeidae (Enchytraeus sp.). Determination of effects on reproduction and survival. ISO 16387. Genève.

ISO (International Organization for Standardization). 2004. Soil Quality - Avoidance test for evaluating the quality of soils and the toxicity of chemicals. Test with earthworms (Eisenia fetida/andrei). ISO Draft 17512. Genève.

Løkke, H. \& van Gestel, C. A. M. 1998. Handbook of Soil Invertebrate Toxicity Tests. Wiley \& Sons, Chichester.

OECD (Organisation for Economic Co-Operation and Development). 1984. Guideline for testing of chemicals No. 207. Earthworm acute toxicity test. Paris.

Römbke, J. \& Federschmidt, A. 1995. Effects of the fungicide Carbendazim on Enchytraeidae in laboratory and field tests. Newsl. Enchytraeidae, 4, 79-96.

Römbke, J. \& Moser, Th. 2002. Validating the enchytraeid reproduction test: organisation and results of an international ringtest. Chemosphere, 46, 1117-1140. 
Römbke, J. \& Schmidt, M. 1999. REM documentation of putative cuticular sense organs of enchytraeids. Newsl. Enchytraeidae (Schmelz, R. M. \& Sühlo, K., eds.), 6, 15-20.

Slimak, K. M. 1997. Avoidance response as a sublethal effect of pesticides on Lumbricus terrestris (Oligochaeta). Soil Biol. Biochem., 29, 713-715.

Stephenson, G. L., Kaushik, A., Kaushik, N. K., Solomon, K. R., Steele, T. \& Scroggins, R. P. 1997. Use of an avoidance-response test to assess the toxicity of contaminated soils to earthworms. In Advances in Earthworm Ecotoxicology (Sheppard, S. C., Bembridge, J. D., Holmstrup, M. \& Posthuma, L., eds.), pp. 67-81. SETAC Press, Pensacola.

Yeardley, R. B., Lazorchak, J. M. \& Gast, L. C. 1996. The potential of an earthworm avoidance test for evaluation of hazardous waste sites. Environ. Toxicol. Chem., 15, 1532-1537.

\title{
Kunstliku ja loodusliku mulla mõju võrdlus liigi Enchytraeus albidus käitumisele laborikatses
}

\author{
Mónica Amorim, Amadeu Soares ja Jörg Römbke
}

Valgeliimuklane Enchytraeus albidus on tüüpiline mullaloom, orgaanilise aine lagundaja. Teda kasutatakse mulla toksilisuse hindamiseks. Katses võrreldi liigi käitumist (reostatud mulla vältimist) kahel substraadil: OECD kunstlikus mullas ja LUFA 2.2 standardses looduslikus mullas, kui mõlemale oli lisatud mitmes kontsentratsioonis fungitsiide Benomyl ja Carbendazim või herbitsiidi Phenmedipham. Ussid eelistasid mulda LUFA 2.2, mistõttu on seda kasutades võimalik mürkidega reostatuse taset täpsemalt hinnata. On soovitatud kasutada selle liigi käitumist viimasel substraadil kui standardtesti. 